\title{
Acquisition as a means for external technology sourcing: complementary, substitutive or both?
}

\author{
Marcus Wagner \\ Chair in Entrepreneurship and Corporate Growth, Julius-Maximilians-University Wuerzburg and \\ Bureau d'Economie Théorique et Appliquée (BETA), Université de Strasbourg*
}

JEL classification: L10, L86, M20

\section{Published as:}

Wagner, M. (2011). Acquisition as a means for external technology sourcing: Complementary, substitutive or both?. Journal of Engineering and Technology Management, 28(4), 283-299.

* correspondence addresses : Stephanstr. 1, 97070 Wuerzburg, Germany, E-mail: marcus.wagner@uniwuerzburg.de, Tel.: 093131 89046, Fax: 0931312101 and 61, Avenue de la Fôret Noire, 67000 Strasbourg, France, E-mail: wagner@cournot.u-strasbg.fr; Tel.: 039024 2099, Fax: 0390242071 


\title{
Acquisition as a means for external technology sourcing: complementary, substitutive or both?
}

\begin{abstract}
This paper addresses the question of how a target firm's innovation activities relate to the acquiring firm's R\&D characteristics, and more specifically, if the former substitute for, or complement the acquirer's activities.

The paper investigates this question in three narrowly-defined high technology industries by analysing the association of three $R \& D$ characteristics of acquiring firms with different measures of acquisition extent and content. The $R \& D$ characteristics referred to are: addressing $R \& D$ efforts, R\&D outputs and absorptive capacity. Data was collected in each case for those firms whose combined sales revenue makes up $80 \%$ of the industry total and is used to test a set of hypotheses derived from extant literature.

The findings of the analysis confirm a substitutive relationship between acquisitions and acquirer research efforts as well as between acquirer and target patent output, whereas absorptive capacity is complementary to acquisition activities. The results reveal that acquirers target firms that hold a large number of patents in the fields where acquirer patenting is weak, and so address weaknesses in their own R\&D output. This finding extends the extant literature on the role of external technology sourcing in the high-technology context.
\end{abstract}




\section{INTRODUCTION}

Innovation activities in high technology industries have become increasingly diverse, especially under the new paradigm of open and community-driven innovation (Pisano, 1990; Lynn et al., 1997; Puranam et al., 2003). As part of this trend, larger firms frequently face make-or-buy dilemmas, especially for radical innovations. This means that acquisitions are a potentially important route to technology sourcing (Dushnitsky and Lenox, 2005; Fey and Birkinshaw, 2005) and hence a relevant topic of management research and theorizing. The relevance of acquisitions is reflected in the estimate of Bruno and Cooper (1982) that the likelihood of acquisition in high technology industries is $32 \%$. Furthermore, acquisitions have been shown to relate positively to the future innovation and financial performance of the acquiring firms (Irwin et al., 1998; Prabhu et al., 2005) which underscores the importance of this topic for management practice. In light of these arguments, this paper analyses the R\&D-related determinants (namely R\&D intensity, patenting intensity and patent stock of the acquiring firms) of the frequency and technological content of acquisitions and goes on to identify them as substituting for or complementing the original $R \& D$ activities of the acquirers.

Whilst earlier research has performed similar analyses across a broader set of industries, this paper focuses on a narrower set of three high technology industries—software, semiconductors and biotechnology. These three industries are particularly suitable to illuminate the issues raised in this paper because acquisitions are a well-established and persistent phenomenon within them (Jack, 2006, 2007). Adding support, Puranam et al. (2006) argue that the information technology and biotechnology industries are very similar with regard to acquisition behaviour aimed at technology sourcing and it has also been suggested that these industries are alike as concerns the role of patenting in their appropriability regimes (Cohen et al., 2000; Klevoriak et al. 1995). 
A narrow industry focus also circumvents another issue encountered when analysing broader sets of industries, namely that the acquiring firms can be of two types: strongly technology oriented or weakly technology oriented. In the former case it has been proposed that acquisitions complement the acquiring firm's knowledge base and in the latter that they substitute for the acquiring firm's own R\&D (Cassiman et al. 2005; Hitt et al., 1991). Therefore, in empirical samples including many industries, we would expect to find both types of acquiring firms and many examples of positive and negative effects for the aforementioned R\&D-related determinants. It would then be difficult to interpret results given that the empirical association is a mix of the opposing associations for both types of firms. Consequently, focussing on a very narrowly defined set of three high technology (and hence strongly technology oriented) industries generates more reliable conclusions, albeit that they are restricted to a specific type of firm. This study uses the occurrence and extent of patenting undertaken by target firms prior to their acquisition as a narrower measure of technology-related acquisitions. This method offers an improvement on the research discussed in the literature review, which largely relies on acquisition counts. These are a limited indicator in so far as they only approximately account for the amount of technological knowledge and intellectual property created by and residing in a target prior to its acquisition. Incorporating the number of patents granted to a target firm prior to its acquisition is a complementary and more precise indicator, since patents of targets allow assessment of the extent of their technological base and the value of the (soon to be) acquired capabilities (Puranam et al., 2003; Hoetker, 2005; Cloodt et al., 2006; Puranam and Srikanth, 2007).

Taken together, the dependent variables of the number of (total and strongly technology-related) acquisitions and the technological content of acquisitions (measured based on the extent of prior patenting by acquired start-ups) as used in this research provide a very complete picture of the 
role of acquisitions in high technology industries. Given that a literature review reveals a gap in the current body of knowledge on technology-related acquisitions with regard to whether they substitute for or complement the internal R\&D activity of acquirers, the substitutive or complementary links with the R\&D determinants of the acquirers will be the focus of the development of the hypotheses here.

By focussing on this aspect in the hypothesis development and by introducing a patent-based, narrower measure of the technology content of acquisitions (and information from this measure to delineate technology-related acquisitions from those with only very minor technological content) alongside acquisition counts, this paper extends extant literature. ${ }^{1}$ In using a target patenting-based measure, the paper further contributes to the literature by providing a more detailed analysis of the link between target and acquirer patenting.

\section{LITERATURE REVIEW}

Technology sourcing through acquisitions is a phenomenon clearly identified in the theoretical and empirical literature on high technology industries (Chakrabarti and Burton, 1983; Capron and Shen, 2007), and economic theory has proposed a number of reasons for such acquisitions (see e.g. Trautwein, 1990; Morris and Hay, 1991; Milgrom and Roberts, 1992). For example, Trautwein (1990) distinguishes theories based on the notion of rational choice and those that perceive acquisitions as process outcomes or macroeconomic phenomena. Rational choice theories essentially relate to the benefits derived from an acquisition by either the owners or managers of a firm (the so-called empire-building theory). For owners, assuming that the stock

\footnotetext{
${ }^{1}$ For example, earlier research only distinguished whether a firm makes no acquisitions in a year, acquires at least one public target, or acquires non-public targets only. With such an approach, it could be the case that a firm acquires ten non-public targets and only one public target but would still fall into the second category. This makes the interpretation of results difficult, particularly if the distribution of public versus non-public targets in such a dummy variable for acquiring at least one public target is unknown. An approach using target patent counts avoids problems of this kind.
} 
market is efficient, acquisitions lead to increased market power, reduced advertising expenditure or efficiency gains impossible to realise without the acquisition. In addition, allocational takeovers or conglomerate mergers aimed at risk reduction are essentially driven by benefits to owners (Morris and Hay, 1991).

Whilst the benefits to owners are only realised if integration is executed properly after the acquisition, as long as the acquirer perceives successful integration to be feasible, that should not influence the propensity to acquire. ${ }^{2}$ As for benefits to managers, empire-building theory proposes that managers pursue acquisitions to increase the resources at their disposal (Williamson, 1964) which indirectly also include revenues or growth potential brought by the acquisition (Marris, 1964), to maximise their own power and leadership position. Given that empire-building theory implies a principal-agent conflict it carries with it a higher likelihood that post-acquisition integration is less extensive and successful (Amihud and Lev, 1981; Trautwein, 1990).

As concerns the empirical literature, a distinction can be made between work discussing links between acquisitions and the innovation activities of firms established in a market (incumbents) in terms of both efforts and outputs, and work on the relationship between acquirers and targets. Concerning the former, two opposing views have been developed in the literature. These are that acquisitions develop either a substitutive or a complementary relationship with the acquirer's own R\&D activities. R\&D activities are commonly proxied by three variables. The first is $R \& D$ intensity, that is, the ratio between $\mathrm{R} \& \mathrm{D}$ expenditure and sales. This variable is frequently proposed as a measure of innovation effort and input (Brouwer and Kleinknecht, 1998; Deeds, 2001). Secondly, R\&D output can be proxied by patenting intensity, that is, the ratio of a firm's patents generated and the size of the firm, which can be understood as a measure of $R \& D$

\footnotetext{
${ }^{2}$ Post-acquisition performance was however an early focus of the literature, (e.g. Chakrabarti and Souder, 1987)
} 
productivity and success (Desyllas and Hughes, 2008; Talke, 2007). Both of these variables are measured on an annual basis with the nominator and denominator being contemporaneous. The third variable is a measure of a firm's own accumulated technological knowledge (an important predictor of acquisition and integration capability) and is defined as its patent stock accumulated over time. In line with extant literature, when adding up patents granted by application year cumulatively over time, the depreciation of the value of the knowledge reflected by these patents is accounted for by applying a 15\% depreciation rate (Ernst, 1998; Hall, 1990; Hall et al. 2007). ${ }^{3}$ As concerns a substitutive relationship, Desyllas and Hughes (2008), analysing the association of innovation with acquisitions in a sample of eight broadly-defined high technology industries, find that decreasing returns from exploiting a firm's existing knowledge base and the choice of making or buying research are the main drivers behind the acquisition of innovative firms. Their results support the notion that acquisitions substitute for a firm's own innovation output and support earlier work by Blonigen and Taylor (2000) who also found a positive relationship between innovation efforts and acquisition.

Similarly, Hitt et al. (1991) argue in the context of technological sourcing, that acquisitions cause lower R\&D and patenting intensities, and state that this is a partial explanation for the poor postmerger performance frequently encountered. ${ }^{4}$ Finally, Zhao (2009) finds that acquiring firms are less innovative prior to the acquisition and that less innovative acquirers benefit more from acquisitions, which in turn supports a substitutive view.

In addition to a substitutive relationship, a complementary link between acquisitions and innovation activities (efforts as well as outputs) has also been proposed. For example, Arora and

\footnotetext{
${ }^{3}$ No adjustments were made to the number of granted patents applied for in the year corresponding to the first year that the firm entered the data set.

${ }^{4}$ Their argument, whilst proposing the same association of a firm's own innovation activities and acquisitions reverses the causality compared to the earlier studies. According to Börsch-Supan and Köke (2002) issues of reverse causality are frequently the case in empirical management research and causality can only be inferred on the basis of theoretical arguments.
} 
Gambardella (1990) find evidence of a complementary relationship in the biotechnology industry. More recently, Cassiman and Veugelers (2006) following Veugelers and Cassiman (1999) find a complementary relationship between acquisitions and a firm's own innovation activities revealed by multi-sector data from the European Community Innovation Survey. However, their results also illustrate that the empirical literature on a substitutive versus a complementary relationship is not unequivocal. Cassiman and Veugelers (2006) find a positive and significant correlation between firms' own innovation activities and a combined external sourcing category that involves acquisitions, but also for example licensing $(r=0.18)$. Compared to this, the correlation between a firm's own innovation activities and a pure acquisition category is negative, yet not significant $(\mathrm{r}=-0.02)$.

One aspect on which the empirical literature is unequivocal, whether viewed from a substitutive or a complementary perspective, is absorptive capacity. Studies from both perspectives support the notion that a complementary relationship exists between acquisitions and absorptive capacity. One approach frequently used to assess the level of an acquirer's absorptive capacity is to evaluate its patent stock accumulated over time, whilst accounting for the depreciation of the value of the knowledge reflected by patents over time (Hall, 1990; Hall et al. 2007). Using this measure, Desyllas and Hughes (2008) find a significant positive association between acquisition activities and the patent stock of acquirers, which suggests complementarity. Similarly, Cassiman and Veugelers (2006) provide empirical evidence that the relationship between the capability to absorb external knowledge and a firm's own innovation activities is complementary. In addition to the empirical literature on the propensity of external technology to be complementary or substitutive, another relevant stream of scholarly work is that on the relationship between acquirers and targets as sources of innovation (e.g. Cassiman et al., 205; von Hippel, 1988). This literature points to the fact that acquisitions may be especially suitable if 
small start-ups come to a point where they are unable to realize their potential due to lack of complementary assets such as distribution channels, or because they need to grow extensively, and relates this to the limited ability for radical innovation of incumbents (Teece, 1986; Henderson, 1995). It therefore suggests a division of scientific labour between market entrants and incumbents that quite naturally leads to their having roles as targets and acquirers, in a system approach to innovation that is ultimately substitutive (Williamson, 1975; Grandstrand and Sjolander, 1990). It is an approach in line with the argument of von Hippel (1988: 5) that “... temporary profits ('economic rents') expected by potential innovators can ... predict the functional source of innovation" (in this case being either the entrant or the incumbent). In opposition, Dessyllas and Hughes (2005) find that from a target perspective, acquisition by a larger firm is explained to only a small degree by innovation related variables. According to them, larger and less profitable startups are acquired. Supporting a substitutive relationship, Lehto and Lehtoranta (2006) find that acquirer success in innovation activity follows the acquisition of a target. In summary, this latter stream of literature is also ambiguous about whether the relationship between acquirers and targets is more often substitutive or complementary. It therefore seems to justify the development of detailed hypotheses to analyse the issue in more detail empirically.

\section{HYPOTHESIS DEVELOPMENT}

This section develops hypotheses based on the issue of complementary versus substitutive (technology-related) acquisitions, as identified by a literature review. Moreover, the hypotheses seek to reveal the particular characteristics of acquiring firms - and here especially those related to R\&D - that motivate the acquisition of innovative start-ups, in terms of the number (both the total and the technology-related acquisitions ) and the technological value of acquisitions 
measured based on the prior patenting activity of the targets. These key explanatory and dependent variables are all derived from or complement extant literature and have been defined in the literature review. For each, hypotheses are derived based on the theoretical arguments for a substitutive versus complementary link. To assist with this, the analysis of the existing theoretical and empirical literature was supplemented with exploratory qualitative interviews with industry experts. 21 interviews of 1-2 hours duration were conducted between October 2005 and April 2008 with senior professionals from the three industries being analysed. Three interviewees were involved in biotechnology, ten were involved with semiconductors and the remaining eight were involved with electronic design automation (EDA). The panel of experts was drawn from large and small firms and from universities and major research centres in America and Europe. Five interviews were carried out by telephone and the remaining interviews in person, and in each industry, at least one interview was carried out in each of the two forms. Interviews were subsequently transcribed and the written material was then coded inductively in order to derive categories using Nvivo software. Coding of the semi-structured interviews was open, i.e. new categories and subcategories were defined as they emerged in the material. This approach is advocated methodologically (e.g. Miles and Huberman, 1994) and has also been applied in similar research settings.

\section{$R \& D$ intensity}

The view that low $R \& D$ and patenting intensity causes acquisition activity is theoretically supported by the literature on obstacles to innovation (e.g. Christensen and Bower, 1996) which posits that there are objective impediments that deter innovation or render it inefficient, especially in larger firms. Two situations need to be distinguished here. The first occurs when the acquirer incurs R\&D cost whilst attempting to innovate, but eventually fails to achieve the 
objective of the innovation. This would relate to a situation where the R\&D output or success is reduced while $R \& D$ intensity remains largely unchanged. Such a situation raises questions about the relationship between patenting intensity and acquisitions - the focus of the next sub-section. The second situation arises when the acquirer is not incurring $R \& D$ cost, in other words, the effort and input is lower. It is this link between $R \& D$ intensity and acquisitions that is the focus of this sub-section. Specific examples for this last link emerge from the qualitative interviews and relate to two main areas, namely those that are firm-internal and those that refer to the market environment (i.e. are firm-external). In the firm-internal segment, one key reason identified in the interviews for acquisition was that the R\&D acquired could not have been conducted by the incumbent company, because it was not feasible due to a lack of capability, critical human capital, or to the innovation in question being very radical for the incumbent organisation (Henderson, 1993). This is illustrated by the following quote from an interviewee in the EDA industry: "When you do something for ten years the same way, to do it differently, it's tough". The second key reason why larger firms in particular do not carry out R\&D themselves and are thus eventually forced to pursue acquisitions is the need for extensive deliberation within the firms (Christensen and Rosenbloom, 1995). As an interviewee in the semiconductor industry says: "Within such a big organization, there is always a lot of politics ... And in a sense it is always a hindrance to .. innovation (to being able) to say: let's do what we need to do. Because there is always some .. political consideration, micro-politics ...”. Therefore, whilst R\&D falling into this category is in principle feasible, implementing it in practice is rather difficult.

In terms of the market environment (i.e. firm-external aspects), the main reason identified in the interviews for not carrying out specific R\&D activities (even if they could well be feasible) is specific customer demands. This is an obstacle that arises even where the R\&D activities are feasible in some respects, as an interviewee from the semiconductor industry describes: "Big 
companies have a cycle, they start small, grow and grow and they serve a lot of customers .. These customers, they lock you into just providing something and ... then you don't have any more money or time to spend on innovation". This issue is also discussed by Christensen (1997) in the context of disruptive innovation, and is a phenomenon also identified by an interviewee from the EDA industry: "you are a big company and this customer is telling you 'I want to have this feature' that is maybe absolutely irrelevant to all the other customers, it is not an innovation but just very simple things and you are at a certain point, were your customer is locking you in ... you are just no longer able to provide ... innovation .. you really have to put a lot of effort into non-innovative stuff”.

The reasons above derived from the literature and the exploratory interviews ultimately point to a substitutive relationship between the R\&D inputs and efforts of acquirers and their acquisitions. Therefore, based on the causal mechanisms developed in the literature and confirmed by the interviews, it can be concluded that the association between $R \& D$ activities and acquisition should be negative, especially for technologically-related acquisitions. This leads to the following hypotheses:

Hla: The R\&D intensity of acquiring firms is negatively associated with the number of acquisitions. HIb: The association proposed in Hla is stronger for technological acquisitions than it is for the acquisitions of a firm in general (i.e. the estimated strength differs significantly between the two). HIc: The R\&D intensity of acquiring firms is negatively associated with the number of patents granted to a target prior to acquisition.

\section{Patenting intensity}

Given the variety of reasons for acquisition identified in the literature review, it may be that in sourcing technology, firms acquire others to address specific weaknesses within their own 
makeup, such as low R\&D output or success (as proxied by patenting intensity) compared to $\mathrm{R} \& \mathrm{D}$ inputs or efforts (as proxied by $\mathrm{R} \& \mathrm{D}$ intensity). Therefore, it is advisable to consider measures relating to $R \& D$ output, like patenting intensity, alongside those relating to $R \& D$ input, which could be more strongly associated with the patent-related characteristics of targets than R\&D intensity - if, that is, acquirers really use their acquisitions to compensate for very specific weaknesses. Comparing the association of $R \& D$ and patenting intensities both with variables attuned to extent of acquisition and with those relating to the patenting activity of targets prior to the acquisition, reveals how acquirers attempt to mitigate their own weaknesses by sourcing external technology. Of course, to the extent that acquirers are rather unspecific in addressing their weaknesses, the links proposed in $\mathrm{H} 1 \mathrm{a}$ and $\mathrm{H} 1 \mathrm{~b}$ with regard to acquisitions in general and more narrowly-defined technological acquisitions should still hold in the case of patenting intensity.

Two justifications emerge from the literature and the exploratory interviews that consistently suggest a substitutive relationship between patenting intensity and acquisitions, and especially their technological content (proxied as the number of patents granted to targets prior to being acquired).

Firstly, some innovations can require radical changes to an organization (e.g. Henderson and Clark, 1990; Leonard-Barton, 1992) which implies that larger firms would need to go through costly and time-consuming learning processes to be able to successfully realize the innovation (Levinthal and March, 1993). Secondly, if the required organisational structures are lacking, then it is extremely difficult for large firms to be successful with certain innovations (Benner and Tushman, 2002; Tushman and Anderson, 1986). Consistent with these theoretical arguments, in the exploratory interviews, respondents confirmed that acquiring the $R \& D$ in question was cheaper than carrying it out in the original firm, and that this was an important motive for 
acquisition. Apart from R\&D acquisitions being less costly than a firm doing its own $R \& D$, two more aspects emerged from the interviews that are consistent with the notion of organisationally radical innovation. The first is that a firm acquiring $R \& D$ can obtain a more certain result than one pursuing its own R\&D path; and the second that time compression diseconomies do motivate acquisitions. As an interviewee from the EDA industry states: “... it makes sense to the big ones to acquire.. Because for them it would take more time to develop the same concept as soon as it is proven on the market".

The issues of certainty, cost and time were also confirmed in interviews in the biotechnology industry, where much emphasis was placed on the frequent problems that large pharmaceutical firms face with regard to their product pipeline. It was suggested that common causes for these problems are the low quality of portfolio management in these large firms; and that large firms tend to be too late to analyse the R\&D activities of smaller firms holding comparative advantages, the result being that those smaller, specialized firms are often acquired in the end. The exploratory interviews also provide evidence that innovation in start-up enterprises is more radical than that found in the market incumbents, which is in line with the arguments identified in extant literature on the comparative innovation activity advantages of smaller firms (Grandstrand and Sjolander, 1990). This means that even when they attempt to innovate, the chances of success for larger firms, in terms of the desired R\&D output being generated, are lower. Of course, if market incumbents anticipate this, they may not spend on R\&D in the first place, but immediately seek to acquire a suitable target. Similar reasoning can be applied to the need for costly and time-consuming learning processes. Therefore, the effects on R\&D intensity and patenting intensity cannot always be separated, since the hurdles faced by incumbents can be classified on a continuum from not innovating at all to attempting to innovate intensively-but ultimately failing. In the former case, the question would be solely about the link between R\&D 
intensity and acquisitions, whereas in the latter case it would be solely about the link between patenting intensity and acquisitions. Between the two extremes, R\&D and patenting intensity are both involved. In any case, however, it emerges from the exploratory interviews that their relationship with acquisitions is substitutive and this notion is also supported by the extant work discussed in the literature review. Therefore, the following hypotheses are formulated with regard to patenting intensity:

H2a: The patenting intensity of acquiring firms is negatively associated with the number of acquisitions.

$H 2 b$ : The association proposed in $\mathrm{H} 2 \mathrm{a}$ is stronger for technological acquisitions than it is for the acquisitions of a firm in general (i.e. the estimated strength differs significantly between the two). H2c: The patenting intensity of acquiring firms is negatively associated with the number of patents granted to the target firms prior to the acquisition.

\section{Patent stock}

For patent stock (as a proxy for absorptive capacity), the evidence is more unequivocal in the literature, so less emphasis was placed on this aspect in the exploratory interviews. However, it still seems wise to test the hypotheses proposed below, since their confirmation would be expected in the context of the overall system of hypotheses. For larger firms to benefit from the information gathered by small firms, absorptive capacity is necessary (Cohen and Levinthal, 1990).

Absorptive capacity refers to a level of technological knowledge residing in a firm that enables it to integrate the technological knowledge gained through the acquisition of a small firm, in an efficient and effective manner. In this study, it is operationalized by means of the acquirer's patent stock. In technology-related acquisitions, absorptive capacity is particularly important, 
since integration is technically more demanding. As discussed in the literature review, a complementary relationship between acquisitions and a firm's own R\&D has been proposed by some scholars, but here, the evidence is more convincing for patent stock (Veugelers and Cassiman, 1999; Cassiman and Veugelers, 2006). This leads to the following hypotheses with regard to patent stock:

H3a: The patent stock of acquiring firms is positively associated with the number of acquisitions. H3b: The association proposed in H3a is stronger for technological acquisitions than it is for the acquisitions of a firm in general (i.e. the estimated strength differs significantly between the two). H3c: The patent stock of acquiring firms is positively associated with the number of patents granted to target firms prior to the acquisition.

\section{QUANTITATIVE EMPIRICAL ANALYSIS}

Data

Data for the quantitative analysis was collected from the SDC Platinum, Bloomberg and Worldscope Disclosure databases as well as the US Patent and Trademark Office (USPTO) website. The data set comprises the largest firms in the EDA, biotechnology and semiconductor industries 1981-2004. Using USPTO patent data is appropriate since a large majority of the firms analysed are US-based and because in high technology industries, non-US firms also commonly register patents at the USPTO. Hence with this approach data from the national patent office which is home of most of the firms is used, yet any "home advantage" of US-based firms is very small. This is because of the very small variation of US and non-US firms' propensity to patent at the USPTO in high technology sectors, for firms in which the US is a major market. 
The dependent variables, namely technological or technologically-related acquisitions as well as the technological content of the latter are defined in this paper following earlier studies. Whether or not an acquisition is as in Cloodt et al. (2006), Puranam et al. (2003) and Puranam and Srikanth (2007) as those, in which the target firm has been granted at least one patent in the five years prior to acquisition. Using patents to gauge technological capabilities is appropriate in a sample of high technology firms since for the latter patenting is common, for example to create collateral for venture capital investments. It is an improvement over earlier approaches using less precise proxies such as a firm being privately held as means to delineate technology-related and other acquisitions, since patents relate more closely to technological aspects. Using a five-year timeframe prior to the acquisition year to measure the level of technological knowledge is somewhat arbitrary, yet this approach has been utilised before (Hoetker, 2005; Cloodt et al., 2006). This is because it is considered a suitable balance between the declining value of knowledge and patent protection-which increases with every year for which protection was granted and the increasing level of knowledge stock with every additional year included to measure the level of technological knowledge (Cloodt et al., 2006).

The patents held by a large acquiring firm are used as a measure of absorptive capacity when used to calculate patent stock, and to evaluate normalised R\&D outputs when used to calculate patent intensity (see the literature review above). All firms forming the top 80 per cent of the market by sales (based on 2004 rankings) were included from each industry, resulting in 14 EDA, 50 semiconductor and 20 biotechnology firms being analysed. ${ }^{5}$ All three industries are R\&Dintensive and characterised by significant acquisition activity.

\footnotetext{
${ }^{5}$ If a firm merged or quit an industry, it is not included in the dataset beyond that point in time.
} 
In the highly cyclical semiconductor industry, the propensity of firms to hold intellectual property rights increased considerably in the US in the 1980s, especially after the formation of a centralized appellate court in 1982 strengthened patent rights (Hall and Ziedonis, 2001). Partly because of this, innovation-related acquisition activity in the industry has increased (Bloningen and Taylor, 2000; Sanchanta, 2007). Other contributory factors include the emergence of semiconductor vendors without their own production facilities, the so-called fabless firms; and greater acknowledgement of the concept of stickiness of knowledge (von Hippel, 1994) in which acquisitions play an important role (Hagedoorn and Duysters, 2002; Puranam et al., 2003; Graebner, 2004).

Innovation-related acquisitions also play an important role in the EDA industry, which focuses on chip design and covers a number of complex processes from abstract design through to chip testing. The industry has a similarly cyclical nature to the semiconductor industry and a relatively concentrated market structure. The EDA industry features three large firms and a significant number of small firms, the latter of which are frequently acquired by the industry's larger firms. Finally, the biotechnology industry is also characterised by strengthening patent rights (especially in the US) and rapid technical change with cumulative technologies. Again, acquisitions are a frequent phenomenon in this industry as are intensive collaboration and cooperation activities (Rothaermel and Deeds, 2004; Pangarkar, 2003). Apart from the stock of patents, data was also collected for the other R\&D-related characteristics of acquiring firms as defined in the literature review, and for other relevant variables mentioned in the empirical literature. Although they are sometimes mentioned in the literature, it was unfortunately not possible to use operating margin and cash flow as measures of profitability in the analysis, since these were empirically highly correlated with R\&D intensity. Therefore, sales growth was used instead as a joint proxy for profitability and industry-related opportunities. Also 
included are dummies for the geographic origin, time of observation and industry (based on the Dow Jones Stock (DJS) classification of the firms), as suggested by the industry characteristics outlined above. ${ }^{6}$ In addition to these variables, controls for leverage and liquidity are included since both affect acquisition levels. Statistics and correlations for all explanatory variables are provided in Table $1 .^{7}$ To avoid truncation bias with regards to patents, the analysis had ultimately to be limited to the 1981 to 2002 period. It was decided that still the 2004 basis for selecting firms could be upheld, since between 2002 and 2004 only marginal changes took place as concerns the largest firms in each industry making up 80 per cent of the market by sales. Given that data was not available for each firm in every year (e.g. because firms had quit the market or merged with others), the consequence is an unbalanced panel with 660 observations.

Insert Table 1 about here

\section{Econometric approach}

Two well-established models exist to analyse panel data, namely random and fixed effects (Johnston and DiNardo, 1997). Since the number of acquisitions and the technological value of acquisitions, as measured based on prior patenting of the acquired start-ups, are all count datanegative binomial random and fixed effects models are estimated for these as independent variables. The difference between the fixed effects and the random effects model is based on whether the time-invariant effects are correlated with the regressors (as for the fixed effects model) or (in case of the random effects model) not. For these models, the specification is:

\footnotetext{
${ }^{6}$ Furthermore, across industries average annual acquisitions and access to complementary assets differ (Teece, 1986). Hence the average number of acquisitions is industry-specific and the industry dummies also control for this. ${ }^{7}$ In variants of the model specification, nonlinear effects of the explanatory variables were considered. For example, in line with Belderbos et al. (2004) the square of R\&D intensity was included, as was an interaction term between R\&D intensity and patenting intensity that accounts for increased complementarity potential. These nonlinear explanatory variables (for which results are available on request) were not significant for any dependent variable and therefore throughout the remainder of the paper results are only reported for the linear model specification as it has been in the majority of the literature to date.
} 


$$
\begin{aligned}
& u_{i t}=c_{i}{ }^{+} \varepsilon_{i . t} \\
& y_{i t}=\alpha+\beta^{\prime} \mathbf{X}_{i t}+c_{i}+e_{i t}
\end{aligned}
$$

where $i=1, \ldots, \mathrm{N}$ are the units under observation, and $t=1, \ldots, T$ the time periods for which data was collected. $y_{i t}$ denotes an acquisition-related dependent variable for firm $i$ in period $t, \mathbf{X}_{i t}$ represents a set of independent variables, $\beta$ ' a vector of coefficients, $c_{i}$ unobserved individual heterogeneity and $e_{i t}$ an idiosyncratic error that satisfies $E\left[e_{i t} \mid \mathbf{X}_{i t}, c_{i}\right]=0$. The random effects model is estimated assuming no correlation between $e_{i t}$ and $c_{i}$. For the fixed effects model, other than the random effects model, the assumption is that the individual effect $c_{i}$ is correlated with the time-variant independent variables $\mathbf{X}_{\mathrm{it}}$. This means that although the basic specification given in (1) and (2) remains, the interpretation differs, in that the disturbance $c_{i}$ is a constant (and thus represented by a dummy variable) for each unit of analysis, which here is each specific firm. The fact that the disturbance is a constant in the fixed effects model implies that all time-invariant variables are dropped during the estimation. To decide which of the two models (random or fixed effects) is more appropriate, the Hausman test is applied. If the Hausman test is significant, then the fixed effects model is more appropriate.

\section{RESULTS}

To quantitatively address the hypotheses developed earlier, the paper analyses the significant associations of the R\&D-related characteristics of acquiring firms (as defined in the literature review) with the level at which large firms acquire, and the degree to which they acquire, patents. Table 2 summarises the results for the total number of acquisitions, both technology-related and those with little or no technological content, for which a significant positive association is found for sales and for patent stock. For the R\&D intensity, the association is significant and negative. 
This means that firms with a high R\&D intensity tend to acquire less on average than those with low R\&D intensity. A company being headquartered in Asia is negatively associated with the total number of acquisitions.

Insert Table 2 about here

Testing for joint significance shows that the industry dummies are jointly significant $\left(\chi^{2}=6.83, p\right.$ $<0.05)$ and the country dummies are jointly nonsignificant $\left(\chi^{2}=5.48, \mathrm{p}=0.14\right)$.

Table 3 shows that for more narrowly technology-related acquisitions (defined as the number of acquisitions of firms that were granted at least one patent), R\&D intensity is negatively, and patent stock positively, associated. Beyond that-being headquartered in Asia has a significant negative effect (as with the total number of acquisitions). Testing for joint significance revealed, that both industry and country dummies are jointly nonsignificant $\left(\chi^{2}=1.11, \mathrm{p}=0.58\right.$ and $\chi^{2}=$ $4.12, \mathrm{p}=0.25$, respectively).

Insert Table 3 about here

As footnote 2 points out, distinguishing between choosing to acquire private or public firms as a proxy for technological proficiency, is a relatively imprecise approach. A more reliable indicator to assess the innovativeness of the acquired start-ups is to evaluate their recent patent stock, and whether they have patented anything recently or not (Puranam and Srikanth, 2007; Puranam et al., 2006). This is done in the models reported in Table 4, for which the dependent variable is the 
total number of patents granted to the acquired start-ups in the five years prior to acquisition and in the acquisition year itself. As can be seen, the main factors significantly associated with the number of patents granted to the acquired firm up to and including the fifth year prior to the acquisition are patent stock (positive), patenting intensity (negative) and whether the company is headquartered in Japan (in both cases negative).

Insert Table 4 about here

As before, testing for joint significance revealed that the industry dummies are jointly significant $\left(\chi^{2}=1.10, p=0.58\right)$ whereas the country dummies are not $\left(\chi^{2}=2.48, p=0.48\right)$.

The semi-structured interviews provided more detailed insights into the rationale behind acquisition across the three industries, and the information essentially corroborates the results of the quantitative analysis.

The qualitative interviews confirm that most of the acquisitions across the three industries analysed are technology-related, and so add justification to the initial choice of industries and helping to better understand the heterogeneity across firms.

Furthermore, the interviews highlight the need to control for industry differences in acquisition frequency as pointed out by one interviewee from the semiconductor industry: "The semiconductor industry is certainly not characterized as much by acquisitions as is EDA". An interviewee from within the EDA industry suggests that low capital intensity is one reason for the proliferation of start-ups, that in turn fuels the acquisition activity, in the area: "I think it is just a lot easier because you can start out with a computer in your bedroom ... There are only 10,000 engineers capable of doing this kind of stuff. So you're working in a fairly small 
environment. The technical community is strong and you can find places, targets of opportunity by going to the technical shows". The point made here also reveals an additional driver of startup activity, the community aspect, and the fact that it leads to a very high level of knowledge exchange.

Compared to arguments supporting the notion of rational choice, the evidence for empirebuilding theory is very limited in the interview data, suggesting in turn, that integration issues after acquisition are less crucial. Nevertheless, it is acknowledged that factors other than purely efficiency concerns are involved. As two of the experts from the EDA and biotechnology areas respectively state: "In the US if you buy someone else then your stock is $10 \%$ or $20 \%$ higher. And ... they use the acquisition to leverage the value that they have" and "The reasons for an acquisition are sometimes not the technology itself, but finance-related. For example, through an acquisition it is much easier to bind the old owners to the new joint entity".

\section{CONCLUSIONS}

As was shown in the section on hypothesis development and the results section, the exploratory interviews carried out in the biotechnology, EDA and semiconductor industries provide evidence that many of the acquisitions in these industries are related to $R \& D$ aspects. One explanation for this is that firms that are not able to pursue an innovation at an acceptable cost, or within an acceptable timeframe, can acquire start-ups to source the necessary technology and to fill in their gaps in capability (Markides and Geroski, 2005). Such activity is possible because of the specific roles of small start-ups and large incumbents, implying a substitutive relationship between a firm's own R\&D and its external acquisitions. On the other hand, it has been suggested that the link between making and buying $\mathrm{R} \& \mathrm{D}$ is complementary, especially as concerns the capability to absorb external knowledge (Cassiman and Veugelers, 2006). This study has specified a set of 
hypotheses to formally test these propositions on the basis of quantitative data and partially on the basis of insights from qualitative interviews. Overall, the results of this testing show that the patenting and R\&D intensities of firms are associated negatively and significantly with firms' acquisition activities, as proposed by the hypotheses.

More specifically, $\mathrm{H} 1 \mathrm{a}$ and $\mathrm{H} 1 \mathrm{~b}$ are confirmed based on the results reported in Tables 2 and 3. In particular, in the case of H1b, the absolute strength of the association of R\&D intensity with the number of acquisitions is more than $25 \%$ higher for technology-related acquisitions than for overall acquisitions, with the difference being significant according to the Chow test $\left(\chi^{2}=3.95, \mathrm{p}\right.$ $<0.05)$. However, $\mathrm{H} 1 \mathrm{c}$ and $\mathrm{H} 2 \mathrm{a}$ are rejected.

$\mathrm{H} 2 \mathrm{~b}$ is somewhat more difficult to interpret, since for both technology-related acquisitions and total acquisitions, the coefficient of patenting intensity is not significant at conventional levels. Therefore, applying a Chow test to establish whether the two coefficients are significantly different from one another provides only limited insight. However, it should be noted that the coefficient for technology-related acquisitions is more than double the absolute value compared to that for acquisitions in general, and is almost conventionally significant at the $10 \%$ level $(\mathrm{p}=$ 0.12). In contrast, the coefficient for acquisitions in general is far from any commonly accepted significance level. Under Bayesian reasoning such a result would be interpreted as at least partial evidence for $\mathrm{H} 2 \mathrm{~b}$ (especially since it is a comparative hypothesis addressing the relation of two point estimators, rather than one point estimator alone). In fact, when performing the Chow test for patenting intensity, the two coefficients for technology-related versus total acquisitions are significantly different from one another. Qualitative interview data also puts the conventional rejection of $\mathrm{H} 2 \mathrm{~b}$ in a somewhat different light, in that as one interviewee in the EDA industry with regard to patenting and numbers of acquisitions, remarked: "right now, well, people in EDA will try to get as much IP [intellectual property] as they can”. 
$\mathrm{H} 2 \mathrm{c}$ is fully supported, indicating a more narrow substitutability between acquirer and target patenting, something that the literature has thus far not tested for. This can potentially be understood as a specific form of rational behaviour by acquiring firms that have weaknesses more in exploitation than exploration. Supporting this interpretation, R\&D intensity is not significant when the number of recent target patents is the dependent variable.

H3a proposing a positive association of patent stock with the number of acquisitions is supported fully. Likewise, $\mathrm{H} 3 \mathrm{c}$ proposing a positive association of patent stock with the number of patents granted to targets also gains support. $\mathrm{H} 3 \mathrm{~b}$, concerning the comparative effect of patent stock, is supported in that the effect is more than doubled in absolute value terms $(0.25$ versus 0.12$)$ for technology-related acquisitions than for total acquisitions, with the Chow test being significant $\left(\left(\chi^{2}=6.22, \mathrm{p}<0.05\right)\right.$

\section{DISCUSSION AND IMPLICATIONS}

Based on the results of the empirical analysis, a number of implications can be drawn for managers and for academics that provide new insights and address questions that have so far not been the focus of the literature on technology and innovation management.

Firstly, in terms of R\&D processes, the empirical findings highlight the importance for managers to consider whether their industry conditions support a complementary role of large incumbents and small entrants for innovation activities. Conditions are conducive to such a division of labour when barriers to product market entry are high for start-ups (as when there is a need for complementary assets) or when the costs of innovating are low (as in the case of software development). As suitable industry conditions are very important for acquisitions aimed at technology sourcing, managers in established firms should constantly analyse and monitor the conditions in their industry, so as to be able to capitalize on any heightened technological 
competition between start-ups, which would have difficulty in entering the product market. This could enable the incumbent firms to mitigate their weaknesses in innovation outcomes-which are to some degree unavoidable in large organizations.

Furthermore, as concerns managers, Schewe (1996) shows that the external acquisition of technologies is an important element of an imitation strategy, which is also advocated by Markides and Geroski (2005) as being very effective for less innovative larger firms. Results here support the contention that when knowledge is sticky (von Hippel, 1988; 1994), acquisitions are an important means to ultimately ensure knowledge transfer. This is very important especially for strongly innovation-driven firms, as it is a way for them to fully realise their innovations. Finally, managers would be well advised to consider technology-related acquisitions, despite the well-documented challenges of post-acquisition integration (e.g. Schweitzer, 2005 Chakrabarti et al., 1994). These results suggest empire-building is not a major driver of technology-related acquisitions, and because the alternative, strategic technology alliances, are more challenging in terms of their longer-term chances of success, according to the evidence of their frequent premature termination (Sadowsky and Duysters, 2008).

Viewed from the academic perspective, these findings largely support the notion that technologyrelated acquisitions compensate for weakening exploitation, as indicated by lower patenting intensity. Moreover, it appears that acquisitions are, from the acquirer's perspective, largely a substitute for their own R\&D, especially if the acquisitions are strongly technology-related. This research also provides new insights into an under-researched area in the technology and innovation management literature, namely how a target's IP endowments relate to an acquirer's R\&D characteristics. More specifically, the current study reveals that an acquirer recognizing its weakness in terms of patents, specifically selects those targets that can mitigate the weakness, in other words, those holding a high number of patents in fields where the acquirer's recent 
patenting has been weak. This finding provides empirical evidence on the behaviour of firms that are unable or unwilling to realize certain types of innovation. As such, the study can be linked to, and somewhat extends, the literature on obstacles to innovation in larger firms. It also connects to the literature on the institutional complementarity of large market incumbents and smaller entrepreneurial entrants in regard to the role of innovation (Granstrand and Sjolander, 1990; Henderson, 1993; Hauschildt 1999).

\section{LIMITATIONS AND SUGGESTIONS FOR FUTURE RESEARCH}

Given that the qualitative interview findings for this research do not provide much evidence in support of managerially-driven acquisitions (in the sense of empire building), it was unfortunately not possible to confirm that the latter subsequently bring heightened integration problems. In not collecting enough information on managerially-driven acquisitions, this study may underestimate their significance. Future empirical research should therefore test for this and the related proposition that managerially-driven acquisitions (especially those with a low technological content) cause more serious integration problems.

One has to distinguish between issues related to owner-driven acquisitions and those affecting managerially-driven (empire-building) acquisitions. In both cases, historic R\&D and patenting intensities and stocks cannot be affected by integration issues, and differing levels of success after integration are not an issue, since the dependent variables in the analysis do not relate at all

to the period after the acquisition. However, one would expect more serious integration problems in managerially-driven acquisitions (Trautwein, 1990) and if past acquisitions were mainly motivated by non-technological considerations (Cloodt et al., 2006). This is an avenue that would benefit from future research. 
In addition, as the qualitative insights from the interviews indicate that cooperation and innovation networks are relevant for firms addressing issues of weakening exploitation and reduced resources available for innovation, but that their roles may differ according to the industry concerned, potential differences between industries should be explored further. As this research concerns itself solely with acquisitions, it was not possible to consider the role of licensing as another option for externally sourcing technology. A more detailed analysis of the interplay of acquisitions and licensing as external sourcing options could be another interesting area of future research.

\section{REFERENCES}

Amihud, Y. and Lev, B. 1981. Risk reduction as a managerial motive for conglomerate mergers. Bell Journal of Economics, 12: 605-617.

Belderbos, R., Carree, M., Diederen, B., Lokshin, B. and Veugelers, R. 2004. Heterogeneity in R\&D cooperation strategies. International Journal of Industrial Organization, 22: 1237-1263. Benner, M.J. and Tushman, M., 2002. Process management and technological innovation: A longitudinal study of the photography and paint industries. Administrative Science Quarterly, 47: 676-706.

Bloningen, B.A. and Taylor, C.T., 2000. R\&D Intensity and Acquisitions in High Technology Industries: Evidence from the US Electronic and Electrical Equipment Industries. Journal of Industrial Economics, 68 (1): 47-70.

Börsch-Supan, A. and Köke, J., 2002. An Applied Econometricians’ View of Empirical Corporate Governance Studies. German Economic Review, 3 (3): 295-326.

Brouwer, E. and Kleinknecht, A. 1999. Innovative output, and a firm's propensity to patent: An exploration of CIS micro data. Research Policy, 28 (6): 615-624. 
Bruno, A.V. and Cooper, A.C., 1982. Patterns of development and acquisitions for Silicon Valley startups. Technovation, 1 (4): 275-290.

Capron, L. and Shen, J.-C., 2007. Acquisitions of Private vs. Public Firms: Private Information, Target Selection and Acquirer Returns. Strategic Management Journal, 28: 891-911.

Cassiman, B. and Veugelers, R., 2006. In Search of Complementarity in Innovation Strategy: Internal R\&D and External Knowledge Acquisition. Management Science, 52 (1): 68-82.

Cassiman, B., Colombo, M.G., Garrone, P., and Veugelers, R., 2005. The impact of M\&A on the R\&D process: An empirical analysis of the role of technological- and market-relatedness.

Research Policy, 34: 195-220.

Chakrabarti, A.K. and Burton, J., 1983. Technological characteristics of mergers and acquisitions in the 1970s in manufacturing industries in the US. Quarterly Review of Economics and Business, 23: 81-90.

Chakrabarti, A.K. and Souder, W.E., 1987. Technology, Innovation and Performance in Corporate Mergers: A Managerial Evaluation, Technovation, 6: 103-114.

Chakrabarti, A.K., Hauschildt, J. and Süverkrüp, C., 1994. Does it pay to acquire technological firms? R\&D Management, 24 (1): 47-56.

Christensen, C.M. (1997). The Innovator's Dilemma. Boston: Harvard Business School Press. Christensen, C.M. and Bower, J.L., 1996. Customer power, strategic investment, and the failure of leading firms. Strategic Management Journal, 17: 197-218.

Christensen, C.M. and Rosenbloom, R.S., 1995. Explaining the attacker's advantage: technological paradigms, organizational dynamics, and the value network. Research Policy, 24 (2): $233-257$. 
Cloodt, M., Hagedoorn, J. and van Kranenburg, H., 2006. Mergers and acquisitions: their effect on the innovative performance of companies in high technology industries. Research Policy, 35: 642-654.

Cohen, W.M. and Levinthal, D.A., 1990. Absorptive capacity: A new perspective on learning and innovation. Administrative Science Quarterly, 35: 128-152.

Cohen, W.M., Nelson R.R. and Walsh J.P., 2000. Protecting their intellectual assets:

Appropriability conditions and why U.S. manufacturing firms patent (or not). National Bureau of Economic Research, Cambridge.

Deeds, D.L., 2001. The role of R\&D intensity, technical development and absorptive capacity in creating entrepreneurial wealth in high technology start-ups, Journal of Engineering and Technology Management, 18: 29-47.

Desyllas, P. and Hughes, A., 2008. Sourcing technological knowledge through corporate acquisition: Evidence from an international sample of high technology firms. Journal of High Technology Management Research, 18 (2): 157-172.

Dodgson, M., Gann, D. and Salter, A., 2008. The Management of Technological Innovation. Oxford University Press, Oxford.

Dushnitsky, G. and Lenox, M.J., 2005. When do firms undertake R\&D by investing in new ventures? Strategic Management Journal, 26: 947-965.

Ernst, H., 1998. Patent portfolios for strategic R\&D planning. Journal of Engineering and Technology Management, 15: 279-308.

Fey, C.F. and Birkinshaw, J., 2005. External sources of knowledge, governance mode, and R\&D performance. Journal of Management, 31: 597-621.

Gans, J.S., Hsu, D. and Stern, S., 2002. When does start-up innovation spur the gale of creative destruction? RAND Journal of Economics, 33 (4): 571-586. 
Graebner, M., 2004. Momentum and serendipity: How acquired leaders create value in the integration of technology firms. Strategic Management Journal, 25: 751-777.

Grandstrand, O. and Sjolander, S., 1990. The acquisition of technology and small firms by large firms. Journal of Economic Behaviour and Organisation, 13: 367-386.

Gulati, R., 2007. Managing Network Resources. Oxford University Press, Oxford and New York. Hagedoorn, J. and Duysters, G., 2002. External sources of innovative capabilities: the preference for strategic alliances or mergers and acquisitions. Journal of Management Studies, 39 (2): 167 188.

Hall, B.H., 1990. The impact of corporate restructuring on industrial research and development. Brookings Papers on Economic Activity, 3: 85-135.

Hall, B.H. and Ziedonis, R.H., 2001. The patent paradox revisited: an empirical study of patenting in the US semiconductor industry, 1979-1995. RAND Journal of Economics, 32 (1): $101-128$

Hall, B.H., Thoma, G. and Torrisi, S., 2007. The Market Value of Patents and R\&D: Evidence From European Firms. Paper presented at the Applied Econometrics Association 96th International Conference "Patent \& Innovation: Econometrics Studies" Strasbourg, 28-29 June 2007.

Hauschildt, J., 1999. Opposition to innovations - destructive or constructive? In: Brockhoff, K., Chakrabarti, A. and Hauschildt, J. (Eds.), The Dynamics of Innovation, Springer, Berlin, 217-240 pp.

Henderson, R., 1993. Underinvestment and incompetence as responses to radical innovation: evidence from the photolithographic alignment equipment industry. RAND Journal of Economics, 24 (2): 248-270. 
Henderson, R. and Clark, K.B., 1990. Architectural Innovation: The Reconfiguration of Existing Product Technologies and the Failure of Established Firms. Administrative Science Quarterly, 35: 9-30.

Hitt, M.A., Hoskisson, R.E., Duane Ireland, R. and Harrison, J.S., 1991. Effects of Acquisitions on R\&D Inputs and Outputs. Academy of Management Journal, 34 (3): 693-706.

Hoetker, G., 2005. How Much You Know Versus How Well I Know You: Selecting a Supplier for a Technically Innovative Component. Strategic Management Journal, 26 (1): 75-96.

Irwin, J.G., Hoffman, J.J. and Lamont, B.T., 1998. The effect of the acquisition of technological innovations on organizational performance: A resource-based view. Journal of Engineering and Technology Management, 15: 25-54.

Jack, A., 2006. M\&A may be best medicine for mid-sized pharma groups. Financial Times, 26th September: 20 .

Jack, A., 2007. AZ to move into vaccines with \$16bn US deal. Financial Times, 24th April: 15. Johnston, J. and DiNardo, J., 1997. Econometric Methods. McGraw-Hill, New York. Klevorick, A.K., Levin, R.C., Nelson, R.R. and Winter, S.G., 1995. On the sources and significance of inter-industry differences in technological opportunities. Research Policy, 24: $185-205$.

Lehto, E. and Lehtoranta, O. 2006. How Do Innovations Affect Mergers and Acquisitions Evidence from Finland? Journal of Industry, Competition and Trade, 6 (1): 5-25. Leonard-Barton, D., 1992. Core capabilities and core rigidities: A paradox in managing new product development. Strategic Management Journal, 13: 111-125.

Levinthal, D.A. and March, J.G., 1993. The Myopia of Learning. Strategic Management Journal, 14: $95-112$. 
Levy, D., 1994. Chaos Theory and Strategy: Theory, Application and Managerial Implications. Strategic Management Journal, 15: 167-178.

Lynn, L.H., Aram, J.D., Reddy, N.M., 1997. Technology communities and innovation communities. Journal of Engineering and Technology Management, 14: 129-145.

Markides C. and Geroski, P., 2005. Fast Second. How Smart Companies bypass Radical Innovation to Enter and Dominate New Markets. Jossey-Bass, San Francisco.

Marris, R. 1964. The Economic Theory of Managerial Capitalism. Free Press, New York.

Milgrom, P.R. and Roberts, J., 1992. Economics, Organizations and Management. Prentice-Hall, Upper Saddle River.

Morris, D.J. and Hay, D.A., 1991. Industrial Economics \& Organisation - Theory \& Evidence. Oxford University Press, Oxford.

Mowery, D.C., Oxley, J.E. and Silverman, B.S., 1998. Technological overlap and interfirm cooperation: implications for the resource-based view of the firm. Research Policy, 27: 507-523. Pangarkar, N., 2003. Determinants of Alliance Duration in Uncertain Environments: The Case of the Biotechnologynology Sector. Long Range Planning, 36: 269-284.

Pangarkar, N. and Klein, S., 2001. The Impacts of Alliance Purpose and Partner Similarity on Alliance Governance. British Journal of Management, 12 (4): 341-353.

Pisano, G.P., 1990. The R\&D boundaries of the firm: an empirical analysis. Administrative Science Quarterly, 35 (1): 153-176.

Prabhu, J.C., Chandy, R.K. and Ellis, M.E., 2005. The Impact of Acquisitions on Innovation: Poison Pill, Placebo, or Tonic? Journal of Marketing, 69: 114-130.

Puranam, P. and Srikanth, K., 2007. What they know vs. what they do: how acquirers leverage technology acquisitions. Strategic Management Journal, 28: 805-825. 
Puranam, P., Singh, H. and Zollo, M., 2003. A Bird in the Hand or Two in the Bush? Integration Trade-offs in Technology-grafting Acquisitions. European Management Journal, 21 (2): 179_ 184.

Puranam, P., Singh, H. and Zollo, M., 2006. Structural integration and innovation in technology grafting acquisitions. Academy of Management Journal, 49: 263-280.

Rothaermel, F.T. and Deeds, D.L., 2004. Exploration and exploitation alliances in biotechnology: a system of new product development. Strategic Management Journal, 25 (3): 201-221.

Sanchanta, M., 2007. Shortlist drawn up for Sanyo chip unit sale. Financial Times, 23rd May: 19. Sangiovanni-Vincentelli, A., 2003. The Tides of EDA. IEEE Design and Test of Computers November-December: 59-74.

Sadowski, B. and Duysters, G., 2008. Strategic technology alliance termination: An empirical investigation. Journal of Engineering and Technology Management, 25: 305-320.

Schewe, G., 1996. Imitation as a strategic option for external acquisition of technology. Journal of Engineering and Technology Management, 13: 55-82.

Schweitzer, L., 2005. Organizational integration of acquired biotechnology companies into pharmaceutical companies: the need for a hybrid approach. Academy of Management Journal, 48 (6): 1051-1074.

Talke, K. 2007. Corporate mindset of innovating firms: Influences on new product performance. Journal of Engineering and Technology Management, 24: 76-91.

Teece, D.J. (1986) Profiting from Technological Innovation: Implications for Integration, Collaboration, Licensing and Public Policy, Research Policy, 15, 285-305.

Trautwein, F., 1990. Merger Motives and Merger Prescriptions. Strategic Management Journal, 11 (4): 283-295. 
Veugelers, R. and Cassiman, B., 1999. Make and buy in innovation strategies: evidence from Belgian manufacturing firms. Research Policy, 28 (1): 63-80.

von Hippel, E., 1988. The Sources of Innovation. Oxford University Press, Oxford.

von Hippel, E., 1994. Sticky Information and the Locus of Problem Solving: Implications for Innovation. Management Science, 40 (4): 429-439.

Wagner, M. (2010) Acquisitions as a means of innovation sourcing by incumbents and growth of technology-oriented ventures. International Journal of Technology Management, in press.

Williamson, O.E. 1964. The Economics of Discretionary Behavior. Prentice-Hall, Englewood Cliffs.

Williamson, O.E., 1975. Markets and hierarchies: Analysis and antitrust implications. Free Press, New York.

Zhao, X., 2009. Technological Innovation and Acquisitions. Management Science, 55 (7): 11701183. 
TABLE 2

\section{RE negative binominal regression, dependent variable: number of total acquisitions}

\begin{tabular}{ll}
\hline Variables & Estimates \\
\hline Financial leverage & -0.0320 \\
(total assets to total equity) & $(0.0628)$ \\
Current ratio & 0.0151 \\
(current assets to current liabilities) & $(0.0312)$ \\
Sales growth & 0.0003 \\
(\% over previous year) & $(0.0005)$ \\
Sales & 0.1728 \\
(natural logarithm of net sales in 1000 €) & $(0.0597)^{* * *}$ \\
R\&D intensity & -0.0034 \\
(R\&D expenditure to net sales in \%) & $(0.0020)^{*}$ \\
Patent stock & 0.1223 \\
(Cumulated number of (depreciated) patents granted) & $(0.0647)^{*}$ \\
Patenting intensity & -0.0010 \\
(Patents granted by application year to net sales) & $(0.0010)$ \\
Company headquartered in Japan & -0.3329 \\
(dummy; 1 = yes; base category: United States) & $(0.4435)$ \\
Company headquartered in Europe & -0.4201 \\
(dummy; 1 = yes; base category: United States) & $(0.4375)$ \\
Company headquartered in Asia & -0.8947 \\
(dummy; 1 = yes; base category: United States) & $(0.4113)^{* *}$ \\
DJS industry Technology (Semiconductor) & 0.7158 \\
(dummy; 1 = yes; base category: Other) & $(0.4667)$ \\
DJS industry Healthcare (Biotechnology) & -0.1581 \\
(dummy; 1 = yes; base category: Other) & $(0.6098)$ \\
Constant & -1.0447 \\
& $(0.9511)$ \\
\hline Log-likelihood & \\
ln(r) & -649.2473 \\
ln(s) & 2.4644 \\
No.value of observations (No. of groups) & 0.5287 \\
Wald Chi2 & $660(81)$ \\
\hline
\end{tabular}

Notes: Significance levels: $* \mathrm{p}<0.1 ; * * \mathrm{p}<0.05 ; * * * \mathrm{p}<0.01$; unbalanced panel data, observations per group: min $=1 ; \max =16$; average $=8.1$; Likelihood-ratio test vs. pooled: $\mathrm{Chi}^{2}=61.07, \mathrm{p}$-value $>\mathrm{Chi}^{2}<0.001$; test for joint significance of year dummies: $\mathrm{Chi}^{2}=35.28, \mathrm{p}$-value $>\mathrm{Chi}^{2}=0.0022$ 
TABLE 3

\section{Random-effects negative binominal regression, dependent variable: number of}

\section{technological acquisitions}

\begin{tabular}{|c|c|}
\hline Variables & Estimates \\
\hline $\begin{array}{l}\text { Financial leverage } \\
\text { (total assets to total equity) }\end{array}$ & $\begin{array}{l}-0.0023 \\
(0.0205)\end{array}$ \\
\hline $\begin{array}{l}\text { Current ratio } \\
\text { (current assets to current liabilities) }\end{array}$ & $\begin{array}{l}0.0007 \\
(0.0409)\end{array}$ \\
\hline $\begin{array}{l}\text { Sales growth } \\
\text { (\% over previous year) }\end{array}$ & $\begin{array}{l}0.0001 \\
(0.0007)\end{array}$ \\
\hline $\begin{array}{l}\text { Sales } \\
\text { (natural logarithm of net sales in } 1000 € \text { ) }\end{array}$ & $\begin{array}{l}0.0648 \\
(0.0687)\end{array}$ \\
\hline $\begin{array}{l}\text { R\&D intensity } \\
\text { (R\&D expenditure to net sales in \%) }\end{array}$ & $\begin{array}{l}-0.0047 \\
(0.0027)^{*}\end{array}$ \\
\hline $\begin{array}{l}\text { Patent stock } \\
\text { (Cumulated number of (depreciated) patents granted) }\end{array}$ & $\begin{array}{l}0.2510 \\
(0.0756)^{* * *}\end{array}$ \\
\hline $\begin{array}{l}\text { Patenting intensity } \\
\text { (Patents granted by application year to net sales) }\end{array}$ & $\begin{array}{l}-0.0021 \\
(0.0013)\end{array}$ \\
\hline $\begin{array}{l}\text { Company headquartered in Japan } \\
\text { (dummy; } 1 \text { = yes; base category: United States) }\end{array}$ & $\begin{array}{l}-0.5081 \\
(0.4540)\end{array}$ \\
\hline $\begin{array}{l}\text { Company headquartered in Europe } \\
\text { (dummy; } 1 \text { = yes; base category: United States) }\end{array}$ & $\begin{array}{l}-0.4839 \\
(0.5012)\end{array}$ \\
\hline $\begin{array}{l}\text { Company headquartered in Asia } \\
\text { (dummy; } 1 \text { = yes; base category: United States) }\end{array}$ & $\begin{array}{l}-0.7727 \\
(0.4550)^{*}\end{array}$ \\
\hline $\begin{array}{l}\text { DJS industry Technology (Semiconductor) } \\
\text { (dummy; } 1 \text { = yes; base category: Other) }\end{array}$ & $\begin{array}{l}0.5041 \\
(0.4849)\end{array}$ \\
\hline $\begin{array}{l}\text { DJS industry Healthcare (Biotechnology) } \\
\text { (dummy; } 1 \text { = yes; base category: Other) }\end{array}$ & $\begin{array}{l}0.4162 \\
(0.6615)\end{array}$ \\
\hline Constant & $\begin{array}{l}0.5236 \\
(2.8283)\end{array}$ \\
\hline $\begin{array}{l}\text { Log-likelihood } \\
\ln (\mathrm{r}) \\
\ln (\mathrm{s})\end{array}$ & $\begin{array}{l}-453.3208 \\
4.1556 \\
0.5022\end{array}$ \\
\hline No. of observations (No. of groups) & $660(81)$ \\
\hline $\begin{array}{l}\text { Wald } \mathrm{Chi}^{2} \\
\text { p-value }\end{array}$ & $\begin{array}{l}64.13 \\
0.0001\end{array}$ \\
\hline $\begin{array}{l}\text { Hausman specification test } \\
\text { Chi }^{2} \\
\text { p-value }\end{array}$ & $\begin{array}{l}0.01 \\
0.9997\end{array}$ \\
\hline
\end{tabular}

Notes: Significance levels: $* \mathrm{p}<0.1 ; * * \mathrm{p}<0.05 ; * * * \mathrm{p}<0.01$; unbalanced panel data, observations per group: $\min$ $=1 ; \max =16$; average $=8.1$; Likelihood-ratio test vs. pooled: $\mathrm{Chi}^{2}=31.40$, $\mathrm{p}$-value $>\mathrm{Chi}^{2}<0.001$; test for joint significance of year dummies: $\mathrm{Chi}^{2}=23.67, \mathrm{p}$-value $>\mathrm{Chi}^{2}=0.0709$ 
TABLE 4

Random-effects negative binominal regression, dependent variable: total number of patents granted to targets in the five years prior to acquisition

\begin{tabular}{ll}
\hline Variables & Estimates \\
\hline Financial leverage & -0.0708 \\
(total assets to total equity) & $(0.0864)$ \\
Current ratio & -0.00001 \\
(current assets to current liabilities) & $(0.0387)$ \\
Sales growth & 0.0002 \\
(\% over previous year) & $(0.0007)$ \\
Sales & 0.0964 \\
(natural logarithm of net sales in 1000 $€$ ) & $(0.0591)$ \\
R\&D intensity & -0.0038 \\
(R\&D expenditure to net sales in \%) & $(0.0026)$ \\
Patent stock & 0.1985 \\
(Cumulated number of (depreciated) patents granted) & $(0.0586)^{* * *}$ \\
Patenting intensity & -0.0020 \\
(Patents granted by application year to net sales) & $(0.0011)^{*}$ \\
Company headquartered in Japan & -0.6016 \\
(dummy; 1 = yes; base category: United States) & $(0.3243)^{*}$ \\
Company headquartered in Europe & -0.6022 \\
(dummy; 1 = yes; base category: United States) & $(0.4078)$ \\
Company headquartered in Asia & -0.4641 \\
(dummy; 1 = yes; base category: United States) & $(0.3605)$ \\
DJS industry Technology (Semiconductor) & 0.3199 \\
(dummy; 1 = yes; base category: Other) & $(0.3589)$ \\
DJS industry Healthcare (Biotechnology) & 0.2616 \\
(dummy; 1 = yes; base category: Other) & $(0.5250)$ \\
Constant & -4.835 \\
& $(0.7613)^{* * *}$ \\
\hline Log-likelihood & \\
Hausman ${ }^{2}$ & -1223.4282 \\
ln(s) $(\mathrm{s}$ ) & -0.9536 \\
No. of observations (No. of groups) & 3.8572 \\
Wald Chiª & $660(81)$ \\
\hline
\end{tabular}

Notes: Significance levels: $* \mathrm{p}<0.1 ; * * \mathrm{p}<0.05 ; * * * \mathrm{p}<0.01$; unbalanced panel data, observations per group: min $=1 ; \max =16$; average $=8.1$; Likelihood-ratio test vs. pooled: $\mathrm{Chi}^{2}=14.27, \mathrm{p}$-value $>\mathrm{Chi}^{2}<0.001$; test for joint significance of year dummies: $\mathrm{Chi}^{2}=10.79, \mathrm{p}$-value $>\mathrm{Chi}^{2}=0.7671$ 
TABLE 1: Summary statistics and correlations ${ }^{\mathbf{a}}$

\begin{tabular}{|c|c|c|c|c|c|c|c|c|c|c|c|c|c|c|c|}
\hline \multirow[t]{2}{*}{ Variables } & \multirow[t]{2}{*}{ Mn. } & \multirow{2}{*}{$\begin{array}{l}\text { Std. } \\
\text { Dev. }\end{array}$} & \multirow[t]{2}{*}{ Min. } & \multirow[t]{2}{*}{ Max. } & \multicolumn{11}{|c|}{ Correlations } \\
\hline & & & & & 1 & 2 & 3 & 4 & 5 & 6 & 7 & 8 & 9 & 10 & 11 \\
\hline $1 \begin{array}{r}\text { Financial } \\
\text { leverage }^{\mathrm{b}}\end{array}$ & 2.35 & 6.43 & 0.72 & 166.11 & - & & & & & & & & & & \\
\hline 2 Current ratio ${ }^{b}$ & 3.65 & 4.47 & 0.33 & 45.67 & $-0.08 * *$ & & & & & & & & & & \\
\hline $\begin{array}{l}3 \text { Sales growth } \\
\text { over last year }^{\text {b }}\end{array}$ & 45.45 & 208.6 & -100 & 3462.9 & 0.05 & $0.19 * * *$ & & & & & & & & & \\
\hline 4 Sales $^{b, c}$ & 9.14 & 2.61 & 2.44 & 15.52 & -0.01 & -0.03 & -0.03 & & & & & & & & \\
\hline 5 R\&D intensity ${ }^{b}$ & 6.48 & 13.46 & 0 & 292.68 & -0.01 & $0.21 * * *$ & 0.04 & $-0.10 * * *$ & & & & & & & \\
\hline $6 \begin{array}{l}\text { Patenting } \\
\text { intensity }{ }^{b}\end{array}$ & 0.41 & 1.36 & -12 & 19.53 & -0.04 & $-0.13 * * *$ & -0.06 & $-0.40 * * *$ & $-0.09 * * *$ & & & & & & \\
\hline 7 Patent stock ${ }^{b, c}$ & 8.56 & 1.31 & 4.75 & 9.53 & -0.02 & $-0.38 * * *$ & $-0.19 * * *$ & 0.05 & $-0.22 * * *$ & $0.30 * * *$ & & & & & \\
\hline $\begin{array}{l}8 \text { Firm headquar- } \\
\text { tered in Japan }\end{array}$ & 0.14 & & 0 & 1 & 0.02 & $-0.18 * * *$ & $-0.09 * *$ & $0.07 *$ & $-0.08 * *$ & -0.01 & $0.46^{* * *}$ & & & & \\
\hline $\begin{array}{l}9 \text { Firm headquar- } \\
\text { tered in Europe }\end{array}$ & 0.07 & & 0 & 1 & -0.01 & $-0.09 * *$ & -0.02 & $0.16^{* * *}$ & -0.04 & $-0.10 * * *$ & -0.03 & $-0.12 * * *$ & & & \\
\hline $\begin{array}{l}10 \text { Firm headquar- } \\
\text { tered in Asia }\end{array}$ & 0.24 & & 0 & 1 & $0.14 * * *$ & $-0.13 * * *$ & 0.02 & $-0.14 * * *$ & $-0.06^{*}$ & $0.07 * *$ & -0.01 & $-0.14 * * *$ & $-0.10 * * *$ & & \\
\hline $\begin{array}{l}11 \text { DJS Technology } \\
\text { (Semiconductor) }\end{array}$ & 0.16 & & 0 & 1 & 0.04 & $-0.34 * * *$ & $-0.07 * *$ & $-0.46 * * *$ & $-0.20 * * *$ & $0.32 * * *$ & $0.16^{* * *}$ & $-0.16 * * *$ & $-0.09 * * *$ & $0.18 * * *$ & \\
\hline $\begin{array}{r}12 \text { DJS Healthcare } \\
\text { (Biotechnology) }\end{array}$ & 0.79 & & 0 & 1 & -0.06 & $0.48 * * *$ & $0.13 * * *$ & $0.48 * * *$ & $0.26 * * *$ & $-0.31 * * *$ & $-0.48 * * *$ & $-0.24 * * *$ & 0.03 & $-0.12 * * *$ & $-0.77 * * *$ \\
\hline $\mathbf{1 3}$ Total acquisitions & 0.71 & 1.31 & 0 & 11 & & & & & & & & & & & \\
\hline $\begin{array}{l}\mathbf{1 4} \text { Technological } \\
\text { acquisitions }\end{array}$ & 0.34 & 0.76 & 0 & 8 & & & & & & & & & & & \\
\hline
\end{tabular}

${ }^{\mathrm{b}}$ Lagged by one year; ${ }^{\mathrm{c}}$ Logarithmized 